\title{
Assessment of Programs and Operation for Consumer Horticultural Education at Agricultural Extension Service Centers in Korea
}

\author{
Hye Won Han, Seung Won Han*, Ji sung Kim, and Kwang jin Kim \\ National Institute of Horticultural \& Herbal Science, RDA, Wanju 55365, South Korea
}

\begin{abstract}
The Purpose of this study is investigated to education program and organization in Korea agricultural extension service center. In most cases, the program has steadily operated from 2014 to 2016 in metropolitan cities, specially, In Busan, the greatest education program has been set up twenty one classes during 2014 2016. This study surveyed 114 departments of 3 Agricultural Research \& Extension Services and 75 Agricultural Technology Centers in 8 metropolitan cities, 9 provinces and 67 cities and counties, which implemented the consumer horticultural education programs in 2016. Twenty one agricultural extension service centers has started the consumer horticulture program undertaking for the first time in 2016. Experienced education program had been conducted to the facilities for the consumer horticulture programs in the agricultural extension service centers and training in the educational farm. Specially The Seoul Metropolitan Government had the largest educational training center in $53.136 \mathrm{~m}^{2}$, with the largest educational farm in Gangwon-do province and the most popular crops were fruit. The research suggested that the consumer horticultural of educational practice and the short \& long term of improvement efforts of latent educational curriculum. Agricultural Technology Centers had lands and facilities for exiting agricultural education and the environment to use nearby farms as education farms by establishing a network. Furthermore reconsidering is needed to improve the content, a systematic study of educational practice reformation plan to improve the quality of educational practice.
\end{abstract}

Keywords: educational farm plan experiment facilities, field laboratory, practical program

\section{Introduction}

Horticultural activities are the general activities of humans that develop social, educational, psychological and physical adaptability and pursue physical rehabilitation and mental recovery by doing a range of activities using plants (Jeong et al., 2014). With regards to the activities. Korean Horticultural Therapy Research Society was founded in November 1997 and the horticultural therapist license was issued for the first time in South Korea in 2000. Since the first issuance, 67 Koreans obtained the Horticultural Therapist Registered-Grade I and 719 Koreans earned the Horticultural Therapist Registered-Grade II as of February 2008 (Park, 2008). Six Koreans were certified as the Welfare Horticultural Therapist

This work was carried out with the support of "Cooperative Research Program for Agriculture Science \& Technology Development (Project No. PJ0118922017)" Rural Development Administration, Republic of Korea.

Received: September 30, 2017, Revised: October 8, 2017, Accepted: October 18, 2017

*Comesponding author: hansgarden@korea.kr 
Supervisors, three Koreans earned the Welfare Horticultural Therapist Registered-Grade I, 220 Koreans acquired the Welfare Horticultural Therapist Registered-Grade II and 46 Koreans earned the Welfare Horticultural Therapist Registered-Grade III in February 2017. In August 2017, two Koreans were certified as the Welfare Horticultural Therapist Supervisors, four Koreans obtained the Welfare Horticultural Therapist Registered-Grade I, 156 Koreans earned the Welfare Horticultural Therapist Registered-Grade II and 41 Koreans received the Welfare Horticultural Therapist Registered-Grade III. Under the institution of the supervision system, the license grade system was reformed into Welfare Horticultural Therapist Supervisor, Welfare Horticultural Therapist Registered-Grade I, Welfare Horticultural Therapist Registered-Grade II and Welfare Horticultural Therapist Registered-Grade III in 2014. Every year, there are an increasing number of facilities adopting horticultural therapy in South Korea.

Since horticultural activities use five senses, they are much used in education as well as therapy. Some of the studies found that horticultural therapy and forest therapy for elderly with dementia, people with intellectual disabilities and infants and children started to be mainly researched from 2007 rather than living horticulture targeting adults or office workers (Baik and Eom, 2015; Kweon and Kwon, 2014). Since 2007, there have been studies on urban agriculture targeting communities in schools, public lands and apartment complexes in the form of school farm or community garden (Oh and Kim, 2014; Jang, 2013) and on therapeutic agriculture for all age groups including children, adolescents and adults (Kang and Kim, 2017).

To give farmers equal opportunities, 165 nationwide rural development agencies (provincial Agricultural Research \& Extension Services and municipal and county Agricultural Technology Centers) have 4,320 agricultural extension workers. Among the agencies, 78 municipal and county agencies are enlightening people about agriculture and implementing the consumer horticultural education programs to expand the target for education into urban consumers and adolescents beyond farmers for popularization and universalization of agricultural technologies. Starting from the education about living horticulture in 2004, various educational programs have been operating ranging from horticultural therapy, urban agriculture and lately therapeutic agriculture. Each city and county is providing a wide variety of specialist courses about horticulture including farmer school, indoor and outdoor kitchen gardener, master gardener, urban agriculture professional and urban agriculture manager.

This study is aimed to be used as a basic resource for developing effective operation guidelines of educational programs by researching the educational courses related to consumer horticulture that have been operated by nationwide municipal and county agricultural technology centers and comparing the specialized programs and educational facilities of each region.

\section{Research Methods}

This study surveyed 114 departments of 3 Agricultural Research \& Extension Services and 75 Agricultural Technology Centers in 8 metropolitan cities, 9 provinces and 67 cities and counties, which implemented the consumer horticultural education programs in 2016 (Fig. 1).

The questionnaire was composed of four categories of organization, education, program and facilities and 14 elements of department unit, number of press office, person in charge, finances, educational expenses, number of subject, period, number of curriculum, practice hours, number, form and scale of facility, number of persons to be admitted and annual use personnel. Based on this questionnaire, this study figured out the educational operation of the consumer horticultural education programs in metropolitan cities, cities and counties (Table 1).

The study analyzed the changes of the professional courses by year and region based on the operation of the consumer 


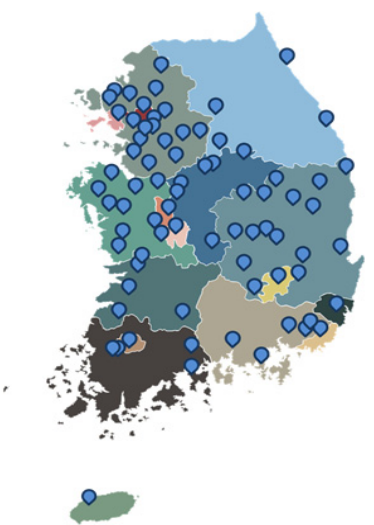

Figure 1. Research on the Korea Agricultural extension service for promoting consumer horticultural education.

Table 1. Consumer horticultural education survey component.

\begin{tabular}{ll}
\hline \multicolumn{1}{c}{ Diagnosis } & \multicolumn{1}{c}{ Content } \\
\hline Organization & Department unit, No. of press office, in charge \\
Education & Finances, Educational expenses, No. of subject \\
Program & Period, No. of curriculum, Practice hours \\
Facilities & Facility No., Form, Scale, No. of persons to be admitted, Annual use personnel \\
\hline
\end{tabular}

horticultural education programs, practical training areas and budget changes of the Agricultural Technology Centers for three years between 2014 and 2016. It investigated the scale of practical training areas rather than education centers because the educational effects of gardening will double with practical training in addition to theory education.

\section{Results and Consideration}

\section{Overview of Consumer Horticultural Education Programs by Region}

The study analyzed the programs operated in the Agricultural Technology Centers and Agricultural Research \& Extension Services in cities and counties across the country for about three years between 2014 and 2016.

The programs were steadily operated in most of the metropolitan cities during the period. In particular, Busan opened the largest number of educational programs including two programs in 2014, 11 in 2015 and 15 in 2016. In addition, 21 municipal and county Agricultural Technology Centers including Sokcho, Suwon and Chungju began to provide the consumer horticultural education programs for the first time in 2016.

In 2014, most of the educational programs were about living horticulture and urban agriculture in the form of agricultural universities. In 2015, the master gardener education programs were mainly provided as well as the professional courses including play garner license, urban farmer and urban agricultural leader, and the programs related to therapeutic agriculture were operated in the Gyeongbuk area. In 2016, the professional courses had been steadily operated from 2014 and 2015, mostly including the horticultural therapy courses for institutionalized children, people with intellectual disabilities and people with atopic dermatitis and the horticultural activities and school farm programs for elementary and middle school students (Table 2).

Aside from the Agricultural Technology Centers, any farms designated by Rural Development Administration across 
Table 2. The local programs operating to the Agricultural extension service from 2016 to 2014.

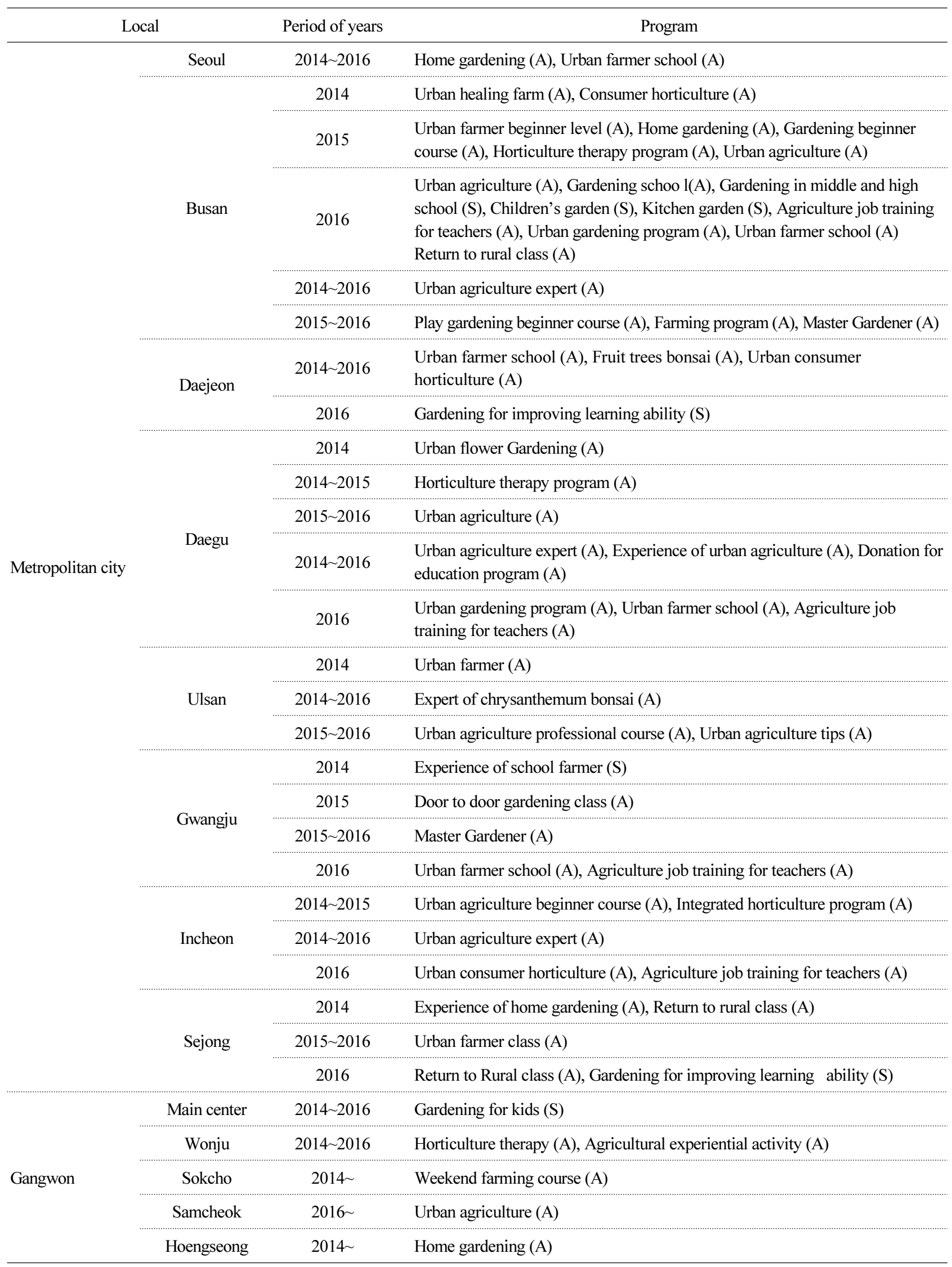


Table 2. The local programs operating to the Agricultural extension service from 2016 to 2014 (Continued).

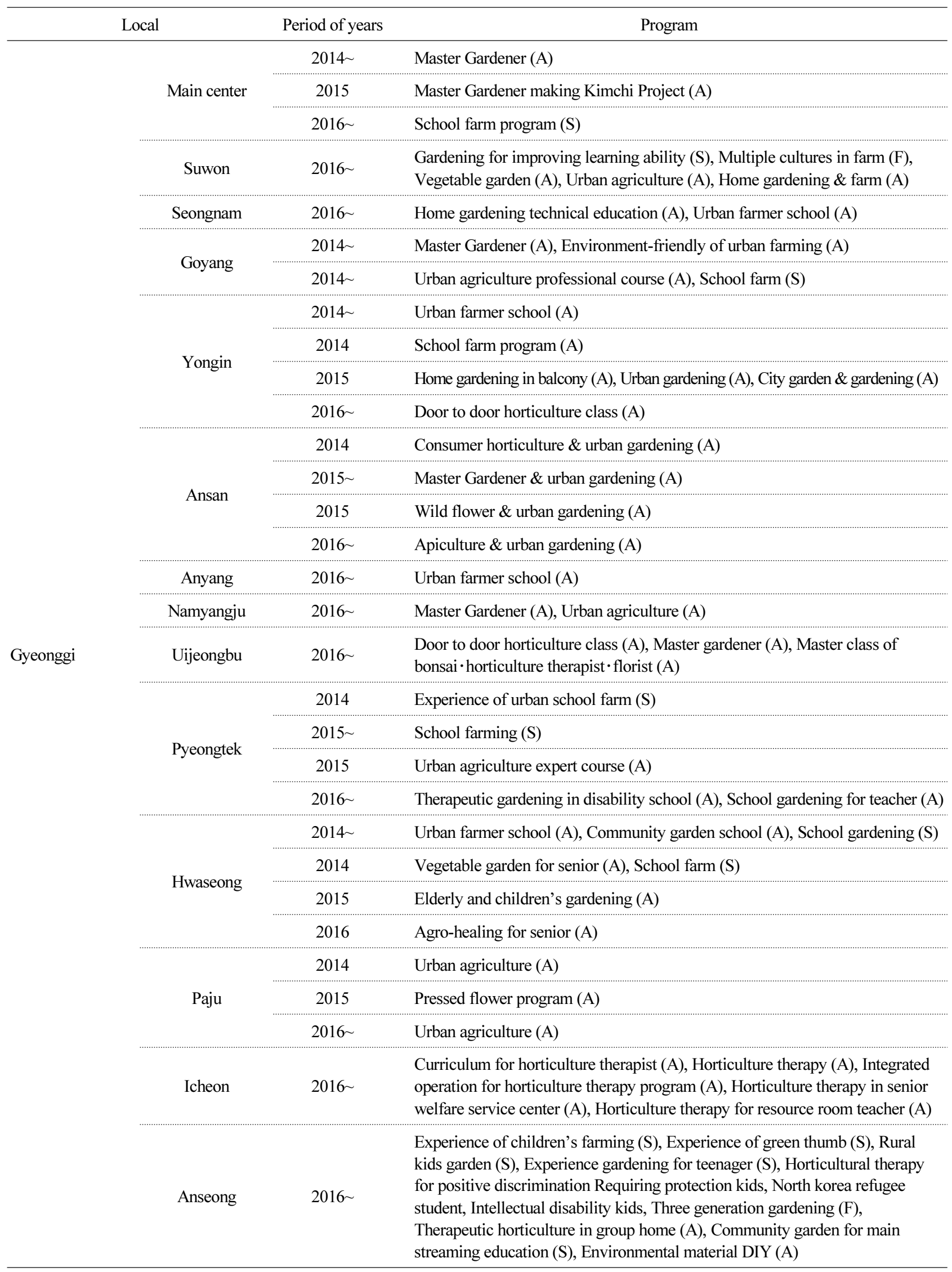


Table 2. The local programs operating to the Agricultural extension service from 2016 to 2014 (Continued).

\begin{tabular}{|c|c|c|c|}
\hline & Local & Period of years & Program \\
\hline \multirow{8}{*}{ Gyeonggi } & \multirow{4}{*}{ Pocheon } & 2014 & $\begin{array}{l}\text { Home gardening (A), Curriculum for beginner of vegetable garden (A), Urban } \\
\text { agriculture leaders (A) }\end{array}$ \\
\hline & & $2015 \sim$ & Vegetable garden program (A), Master Gardener (A) \\
\hline & & 2015 & Home gardening (A) \\
\hline & & $2016 \sim$ & $\begin{array}{l}\text { Urban agriculture (A), Door to door gardening class (S), Chrysanthemum } \\
\text { bonsai (A) }\end{array}$ \\
\hline & \multirow{2}{*}{ Yeoju } & $2014 \sim 2015$ & Urban agriculture $(\mathrm{A})$ \\
\hline & & $2016 \sim$ & Consumer horticulture (A) \\
\hline & \multirow{2}{*}{ Gwacheon } & 2014 & Urban farmer leader class (A) \\
\hline & & $2015 \sim$ & Urban agriculture professional course (A) \\
\hline \multirow{11}{*}{ Chungbuk } & \multirow{2}{*}{ Cheongju } & $2014 \sim 2015$ & Urban agriculture (A) \\
\hline & & $2015 \sim$ & Urban agriculture professional course (A) \\
\hline & Chungju & $2016 \sim$ & Urban agriculture (A), Home gardening (A) \\
\hline & \multirow{2}{*}{ Jecheon } & 2014 & Gardening \& green life (A) \\
\hline & & $2015 \sim$ & Gardening activity (A) \\
\hline & Okcheon & $2014 \sim$ & Gardening activity (A) \\
\hline & \multirow{3}{*}{ Yeongdong } & $2014 \sim$ & Team project in garden $(\mathrm{A})$ \\
\hline & & $2015 \sim$ & Item by item garden society (A) \\
\hline & & $2016 \sim$ & Consumer horticulture course (A) \\
\hline & Jincheon & $2016 \sim$ & Chrysanthemum research society (A) \\
\hline & Eumseong & $2015 \sim$ & Urban agriculture $(\mathrm{A})$ \\
\hline \multirow{14}{*}{ Chungnam } & \multirow{4}{*}{ Cheonan } & 2014 & Urban agriculture (A), Vegetable Garden (A), Cultivation of flower (A) \\
\hline & & $2015 \sim$ & Urban agriculture professional course (A), A gardening class with parents $(\mathrm{F})$ \\
\hline & & 2015 & Urban horticulture (A), Home gardening (A), vegetable garden (A) \\
\hline & & $2016 \sim$ & $\begin{array}{l}\text { Children's plant observation experience (S), Urban horticulture (A), Consumer } \\
\text { horticulture courses (A) }\end{array}$ \\
\hline & \multirow{2}{*}{ Gongju } & 2014 & Experience of nature for citizen (A) \\
\hline & & $2016 \sim$ & Agro-healing tourism (A) \\
\hline & \multirow{2}{*}{ Boryeong } & 2014 & Urban agriculture $(\mathrm{A})$ \\
\hline & & $2015 \sim$ & Indoor gardening $(\mathrm{A})$ \\
\hline & Seosan & 2014 & Home gardening (A), Urban agriculture (A) \\
\hline & \multirow{2}{*}{ Gyeryong } & 2014 2016 & Hints on plant management (A) \\
\hline & & $2016 \sim$ & Urban farmer school (A), Ginseng potting cultivation in veranda (A) \\
\hline & \multirow{3}{*}{ Dangjin } & 2014 2016 & chrysanthemum growing (A), Wild flower growing (A) \\
\hline & & 2014 & $\begin{array}{l}\text { Urban agriculture (A), Consumers agriculture class (A), Life gardening } \\
\text { experience education (A) }\end{array}$ \\
\hline & & $2016 \sim$ & Rural vocational education for elementary and secondary teachers (A) \\
\hline
\end{tabular}


Table 2. The local programs operating to the Agricultural extension service from 2016 to 2014 (Continued).

\begin{tabular}{|c|c|c|c|}
\hline & Local & Period of years & Program \\
\hline \multirow{10}{*}{ Chungnam } & \multirow{3}{*}{ Buyeo } & $2014 \sim 2016$ & Chrysanthemum growing (A) \\
\hline & & 2015 & Pressed flower program (A) \\
\hline & & $2015 \sim$ & Home gardening (A) \\
\hline & Seocheon & $2016 \sim$ & School farm (S) \\
\hline & \multirow{3}{*}{ Hongseong } & 2014 & $\begin{array}{l}\text { Horticulture activities (A), Agro-healing (A), chrysanthemum growing (A), } \\
\text { Landscaping trees growing (A), School farm (A) }\end{array}$ \\
\hline & & 2015 & Bonsai education (A), Urban residents gardening (A) \\
\hline & & $2016 \sim$ & $\begin{array}{l}\text { Agro-healing (A), gardening (A), School farm (S), Pressed flower program (A), } \\
\text { Wild flower growing (A), Horticulture therapy program (A) }\end{array}$ \\
\hline & \multirow{3}{*}{ Yesan } & $2014 \sim 2015$ & Chrysanthemum bonsai (A), Wild flower (A) \\
\hline & & 2014 & Flower arrangement (A), Home gardening (A) \\
\hline & & $2016 \sim$ & Chrysanthemum bonsai (A), Urban agriculture (A) \\
\hline \multirow{23}{*}{ Gyeongbuk } & \multirow{4}{*}{ Pohang } & $2014 \sim 2016$ & An exhibition of wildflower in Pohang (A) \\
\hline & & 2014 & Home gardening (A), Agro-healing training (A) \\
\hline & & $2014 \sim 2015$ & Urban agriculture (A) \\
\hline & & $2016 \sim$ & Return to Rural class (A) \\
\hline & Gimcheon & 2015 & Agro-healing activity (A) \\
\hline & \multirow{2}{*}{ Andong } & 2014 & Curriculum for Horticulture therapist (A) \\
\hline & & 2015 & Chrysanthemum growing (A) \\
\hline & \multirow{4}{*}{ Yeongju } & 2014 & Home gardening (A) \\
\hline & & $2015 \sim$ & Agro-healing activity for children (S) \\
\hline & & 2015 & Agro-healing activity (A) \\
\hline & & $2016 \sim$ & $\begin{array}{l}\text { Home Gardening for improve learning ability (S), Course experience report of } \\
\text { middle school } 2016 \text { (S) }\end{array}$ \\
\hline & Yeongcheon & 2014 & Home gardening (A) \\
\hline & Sangju & $2015 \sim$ & Master Gardener (A) \\
\hline & Gyeongsan & $2014 \sim$ & Home Gardening (A) \\
\hline & \multirow{2}{*}{ Gunwi } & 2014 & Home Gardening (A) \\
\hline & & 2015 & Agro-healing activity (A) \\
\hline & \multirow{2}{*}{ Cheongsong } & 2014 & Home Gardening (A) \\
\hline & & 2015 & Agro-healing education and tour (A) \\
\hline & \multirow{2}{*}{ Yeongyang } & 2015 & Agro-healing activity (A) \\
\hline & & $2016 \sim$ & Flower technical training (A) \\
\hline & Goryeong & 2015 & Home gardening (A) \\
\hline & \multirow{2}{*}{ Seongju } & $2014 \sim$ & Bonsai education (A) \\
\hline & & $2014,2016 \sim$ & Flower cultivation program (A) \\
\hline
\end{tabular}


Table 2. The local programs operating to the Agricultural extension service from 2016 to 2014 (Continued).

\begin{tabular}{|c|c|c|c|}
\hline & Local & Period of years & Program \\
\hline \multirow{12}{*}{ Gyeongbuk } & \multirow{6}{*}{ Chilgok } & $2014 \sim$ & Horticulture therapy for disabled person (A) \\
\hline & & 2014 & Horticulture therapy for multi-cultural family $(\mathrm{F})$ \\
\hline & & $2014,2016 \sim$ & Horticulture therapy for schoolchild (S) \\
\hline & & $2015 \sim$ & Vegetable garden for senior (A) \\
\hline & & 2015 & A Horticulture therapy for multi-cultural (F), Horticulture therapy (A) \\
\hline & & 2016 & Horticulture therapy (A), School farm (S) \\
\hline & \multirow{2}{*}{ Yecheon } & $2014 \sim 2015$ & Chrysanthemum and wild flower growing (A) \\
\hline & & $2015 \sim$ & Wild flower (A) \\
\hline & \multirow{4}{*}{ Uljin } & 2014 & Home gardening (A) \\
\hline & & $2014 \sim 2015$ & Benchmark a gardening course (A) \\
\hline & & 2015 & $\begin{array}{l}\text { Chrysanthemum growing (A), Gyeongsangbuk-do flower exposition tour and } \\
\text { education (A) }\end{array}$ \\
\hline & & 2014, 2016 & Gyeongsangbuk-do flower exposition education (A) \\
\hline \multirow{14}{*}{ Gyeongnam } & $\begin{array}{c}\text { Agriculture } \\
\text { Research Service }\end{array}$ & $2016 \sim$ & Horticulture therapy Univ. (S) \\
\hline & Changwon & $2014 \sim 2015$ & Urban farmer school (A) \\
\hline & \multirow{2}{*}{ Tongyeong } & 2014 & Urban horticulture (A) \\
\hline & & 2015 & Urban farmer school (A) \\
\hline & \multirow{2}{*}{ Sacheon } & 2014 & Urban farmer school (A), Gardening (A) \\
\hline & & $2016 \sim$ & Urban agriculture \\
\hline & \multirow{6}{*}{ Gimhae } & $2014 \sim$ & $\begin{array}{l}\text { A gardening class with parents }(\mathrm{F}), \text { A gardening class for multi-cultural kids } \\
\text { (S), Urban agriculture professional course (A), Urban farmer (A) }\end{array}$ \\
\hline & & 2014 & Urban agriculture professional course (A) \\
\hline & & $2014 \sim 2015$ & Home gardening (A) \\
\hline & & 2015 & Child garden (S), School farm (S) \\
\hline & & $2015 \sim$ & Master Gardener (A) \\
\hline & & 2016 & Vegetable garden in kindergarten (S) \\
\hline & \multirow{2}{*}{ Yangsan } & $2014 \sim$ & Urban farmer school (A) \\
\hline & & $2016 \sim$ & Gardening for kids (S) \\
\hline \multirow{6}{*}{ Jeonbuk } & Jeonju & $2016 \sim$ & $\begin{array}{l}\text { Gardening for improve learning ability (S), Urban agriculture professional } \\
\text { course (A) }\end{array}$ \\
\hline & Iksan & $2016 \sim$ & Urban agriculture (A) \\
\hline & \multirow{2}{*}{ Jeongeup } & 2014 & Medicinal crops class (A) \\
\hline & & $2015 \sim$ & Wild plants class (A) \\
\hline & Namwon & $2016 \sim$ & Chrysanthemum bonsai (A) \\
\hline & Gochang & $2016 \sim$ & Agro-healing course (A) \\
\hline
\end{tabular}


Table 2. The local programs operating to the Agricultural extension service from 2016 to 2014 (Continued).

\begin{tabular}{|c|c|c|c|}
\hline & Local & Period of years & Program \\
\hline \multirow{8}{*}{ Jeonnam } & $\begin{array}{l}\text { Agriculture } \\
\text { Research Service }\end{array}$ & $2015 \sim$ & Urban agriculture professional course (A) \\
\hline & \multirow{3}{*}{ Yeosu } & 2014 2016 & Home gardening (A), Gardening for silver generation (A) \\
\hline & & 2014 & Family gardening activities in summer $(\mathrm{F})$ \\
\hline & & $2015 \sim$ & A gardening class with parents $(\mathrm{F})$ \\
\hline & \multirow{3}{*}{ Suncheon } & 2014 & $\begin{array}{l}\text { Urban farmer school (A), Urban agriculture professional course (A), Children's } \\
\text { natural school (S) }\end{array}$ \\
\hline & & 2015 & ecological school of agriculture (S) \\
\hline & & $2016 \sim$ & $\begin{array}{l}\text { Master Gardener (A), Urban agriculture professional course (A), Farmer school } \\
\text { for children (S) }\end{array}$ \\
\hline & Naju & $2016 \sim$ & A garden box (A) \\
\hline \multirow{3}{*}{ Jeju } & & 2014 2016 & Urban agriculture $(\mathrm{A})$ \\
\hline & & $2014 \sim 2015$ & Master Gardener (A) \\
\hline & & $2016 \sim$ & School farm (S) \\
\hline
\end{tabular}

$\begin{array}{lll}\text { (A) A curriculum for adult } & \text { (S) A curriculum for student } \quad \text { (F) A curriculum for family }\end{array}$

the country can participate in the education programs in operation with various crops and themes. Approximately 16 times more agricultural educational farms were distributed in cities and counties than in metropolitan cities.

Total 557 educational farms were distributed on 12 crops including food, fruit trees, vegetables, flowers, mushrooms and herbs and insects. Among them, Gangwon Province had 70 educational farms, which was the highest number, followed by Gyeongnam with 69 farms, Gyeongbuk with 63 farms and Chungnam with 62 farms.

The most popular crops in 557 farms were fruit trees, which were mainly grown in 105 farms, followed by vegetables in 76 farms and flowers in 64 farms.

According to the review of the number and operation time of the consumer horticultural education programs by year in cities and counties nationwide for about three years between 2014 and 2016, the number and operation hour almost doubled in 2016 from 2015. Busan metropolitan city expanded its consumer horticultural programs compared to other cities and counties as agricultural education in the city increased by 2.2 times in 2015 from 2014. Gwangju had continued to increase the number of programs since 2014 and Jeju had provided the consumer horticultural educational programs from 2015 (Fig. 2). The number of the consumer horticultural education programs had steadily increased in eleven regions including Busan, Pyeongtaek and Chilgok. Gyeonggi Province, where new projects were launched in eight cities including Suwon and Seongnam in 2016, provided 3.6 times more educational programs for 2.7 times more hours, which turned out to be the biggest change (Fig. 3). The Ganwon area with less population than other cities and counties had been actively operating the consumer horticultural education programs based on Wonju, in which the provincial government was located. Samcheok had been steadily operating the educational programs in the Agricultural Research \& Extension Services and four regions under its newly launched project in 2016 (Fig. 4). The Jeolla area provided a lower number of educational courses related to the consumer horticultural education programs than other regions with only 3 programs in 2014, but was quickly expanding the programs by starting new projects in four regions including the Agricultural Research \& Extension Services in 2015 and additional five regions in 2016 (Fig. 5). The Chungcheong area had operated 

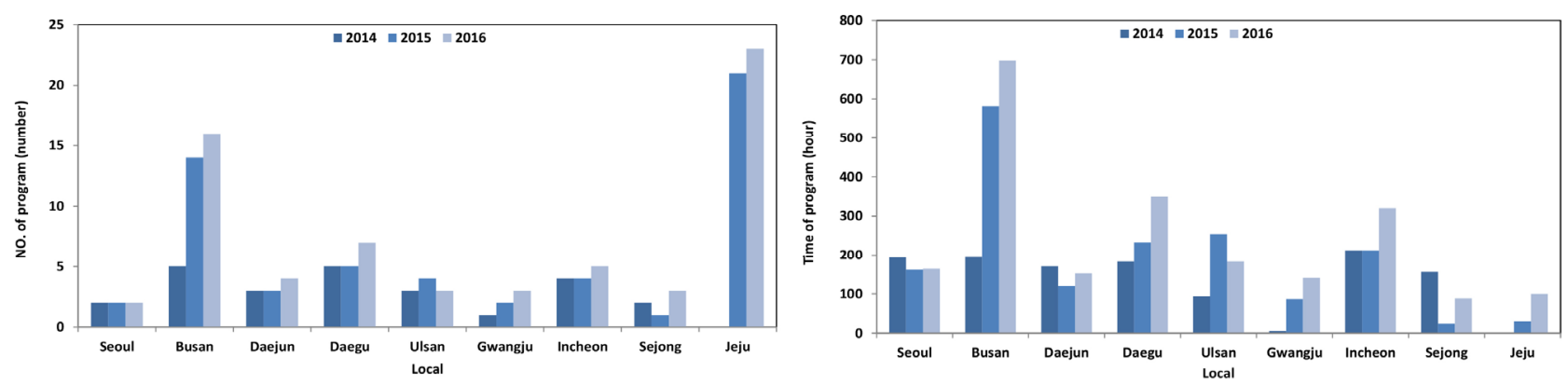

Figure 2. The number and time of consumer horticultural education programs in Metropolitan cities from 2014 to 2016.

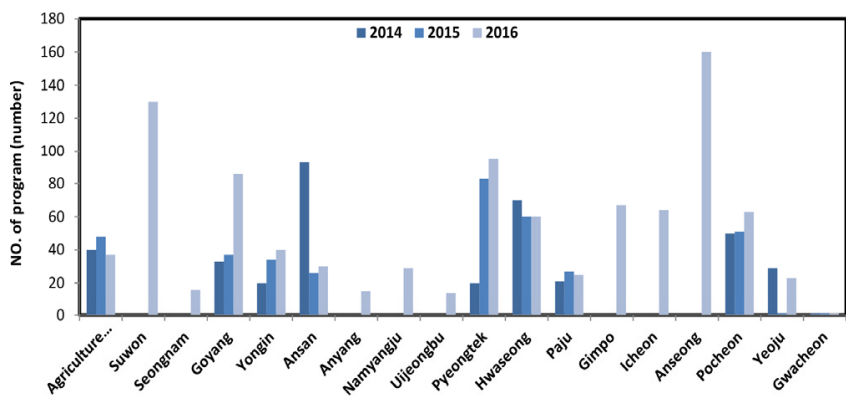

Local

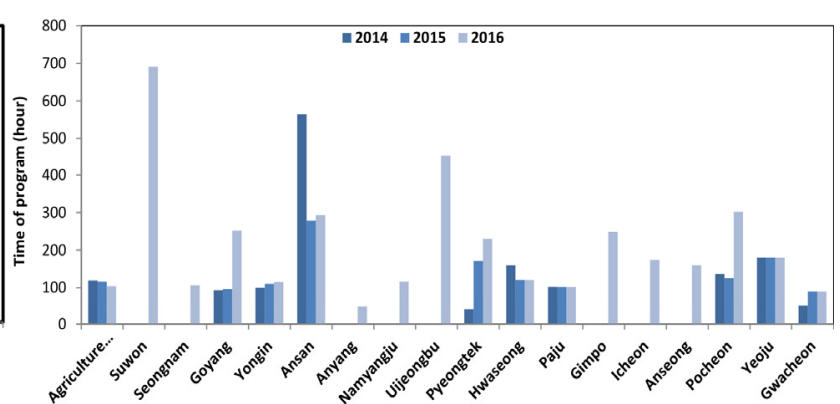

Local

Figure 3. The number and time of consumer horticultural education programs in Gyeonggi from 2014 to 2016.
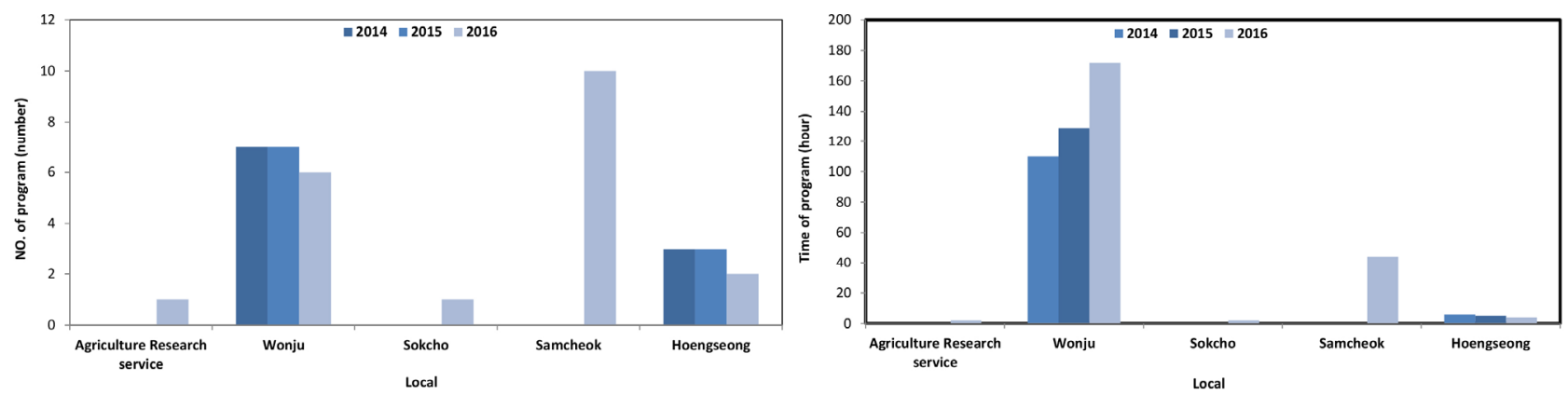

Figure 4. The number and time of consumer horticultural education programs in Gangwon from 2014 to 2016.
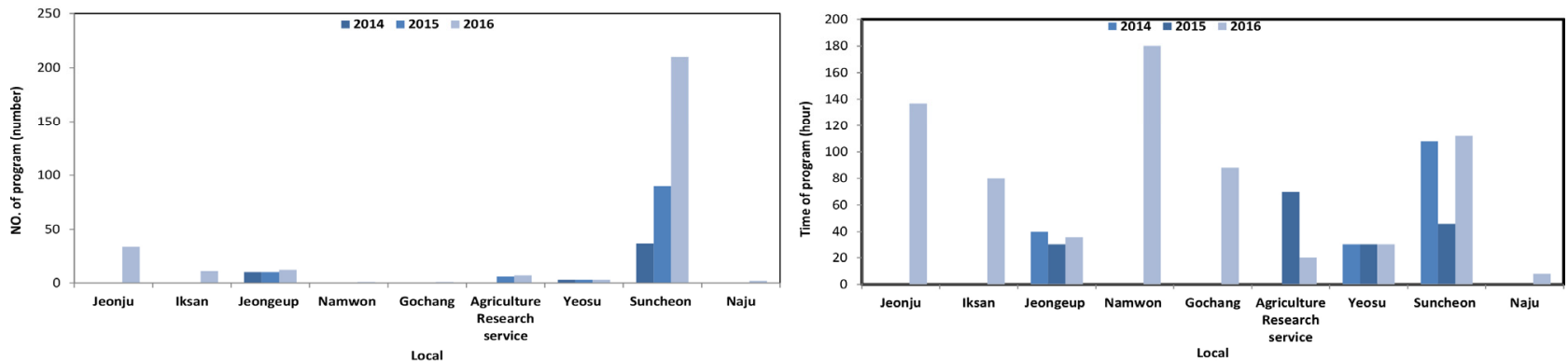

Figure 5. The number and time of consumer horticultural education programs in Jeolla 2014 to 2016.

the consumer horticultural education programs based on Cheongju. Three regions including Chungju started the new projects in 2016 and the programs were fast expanding to Gongju and Yesan, which experienced the movement of population due to the relocation of the Chungnam provincial government building (Fig. 6). Gyeongsang Province had increased support for the programs in three areas including Yeongju and the number of the consumer horticultural 

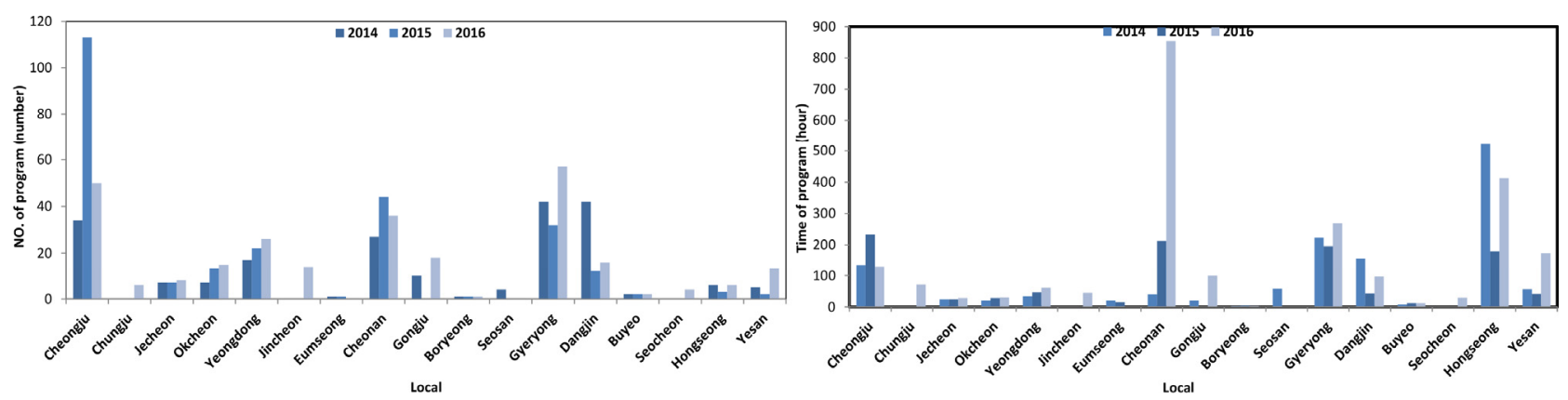

Fgure 6. The number and time of consumer horticultural education programs in Chungcheong from 2014 to 2016.
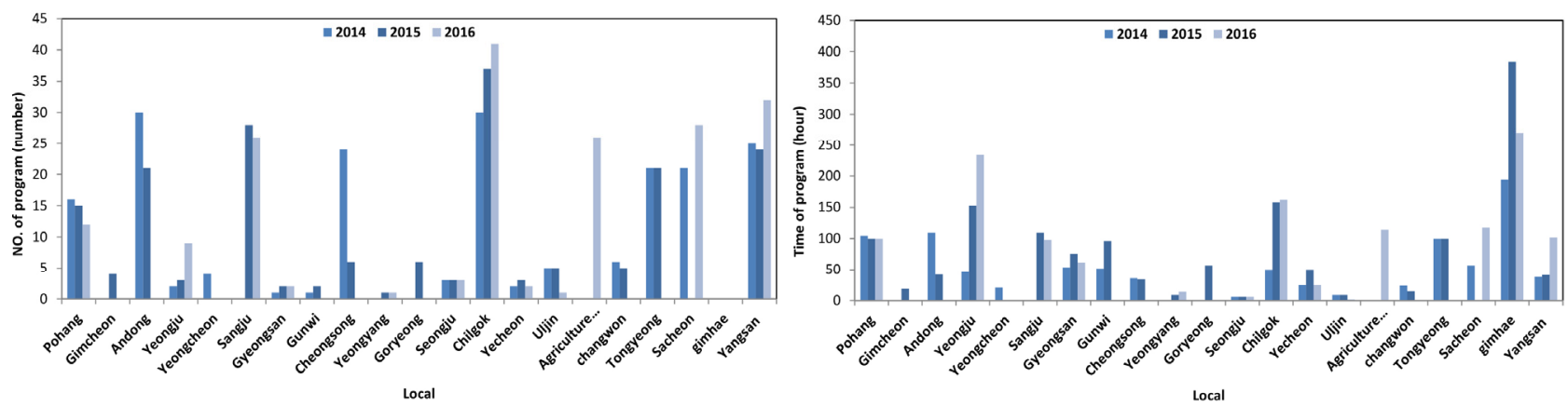

Figure 7. The number and time of consumer horticultural education programs in Gyeongsang from 2014 to 2016.

education programs had been on the decline in six regions with a decreasing population. Gyeongnam Agricultural Research \& Extension Services in Changwon started a large scale new program in 2016 (Fig. 7).

\section{Ovenview of the Organization and Facility of the Consumer Horticultural Education Programs by Region}

The following is the organization and overview of the consumer horticultural education programs in Agricultural Technology Centers in metropolitan cities, cities and counties across the country in 2016 . The programs were operated by 134 workers in 114 departments of 78 Agricultural Technology Centers (Table 3).

The educational effects can double when practical education is provided along with theory education in the consumer horticultural education programs. As an example of work-oriented education, learning on plants is not enough by only observing the plants but can be completed with first-hand experiences of students. It is possible to increase the awareness of students of the learning content through work-oriented education such as seeding and fertilizing plants, keeps body healthy, learn the preciousness of life by cultivating the plants with affection that students personally planted and provide

Table 3. The numbers of departments and specialists to operate the consumer horticultural programs at agricultural extension service centers in cites or provinces.

\begin{tabular}{lcccccccc}
\hline & Seoul & Busan & Daejeon & Daegu & Ulsan & Gwangju & Incheon & Sejong \\
\hline The No. of department & 2 & 2 & 1 & 2 & 1 & 1 & 1 & 1 \\
Head count & 9 & 10 & 1 & 4 & 3 & 3 & 3 & 1.5 \\
\hline & Gangwon & Gyeonggi & Chungbuk & Chungnam & Gyeongbuk Gyeongnam & Jeonbuk & Jeonnam & Jeju \\
\hline The No. of department & 4 & 28 & 11 & 11 & 19 & 17 & 5 & 5 \\
Head count & 1.7 & 39.5 & 8 & 17 & 14.4 & 4.8 & 5 & 6.1 \\
\hline
\end{tabular}




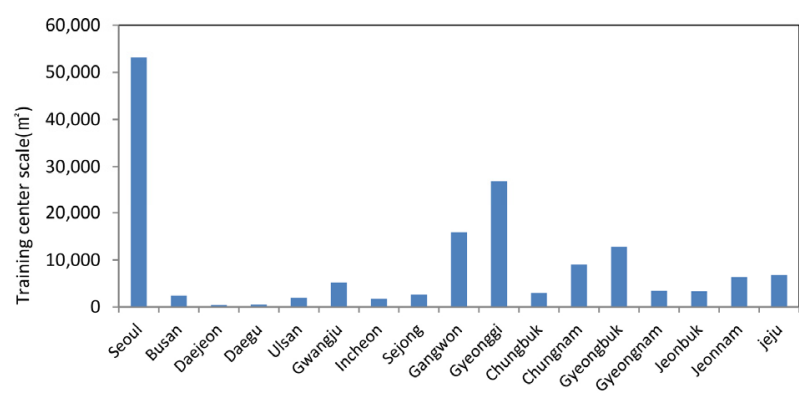

Figure 8. The national educational training center scale

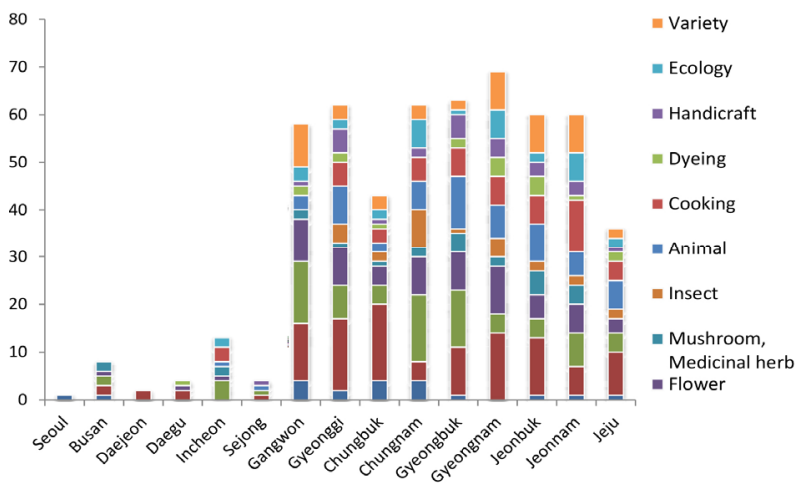

Figure 9. Classification of curriculum by thematic education farms

an opportunity to take interests in the nature, all of which help students's holistic development (Park, 2002).

Municipal and county Agricultural Technology Centers had an advantage over private centers as they had experimental fields and management facilities. The analysis results of the scale of the practical training areas were as shown in Fig. 8 and the overview of the farms designated by Rural Development Administration where various educational programs were provided was indicated in Fig. 9.

In terms of the scale, Seoul Agricultural Technology Center with the highest number of consumers had five practical training areas sized $53,136 \mathrm{~m}^{2}$ in total including the nature exploration area, followed by Gyeonggi $\left(56,888 \mathrm{~m}^{2}\right)$, Gangwon $\left(15,884 \mathrm{~m}^{2}\right)$ and Gyeongbuk $\left(12,781 \mathrm{~m}^{2}\right)$. Among the regions with more than five practical training areas, Dangjin had the largest number of practical training areas, which was seven, but in a smaller size of $4,584 \mathrm{~m}^{2}$, followed by Yeongju with six training areas, Yangsan with five areas and Suwon, Yeosu and Suncheon with four areas. Each practical training area was in different sizes but the average size was 1,306 $\mathrm{m}^{2}$ per training area. By considering the number of allowed students at a time, it is identified that the educational effects can be improved by expanding the size of the practical training areas to $1,000 \mathrm{~m}^{2}$ depending on the themes (Fig. 8).

Approximately 16 times more agricultural education farms were distributed in cities and counties than metropolitan cities. All over the nation, 557 education farms were distributed for 12 crops including food, fruit trees, vegetables, flowers, mushrooms and herbs and insects. Among them, Gangwon Province had the highest number of education farms, which was 70, followed by Gyeongnam with 69 farms, Gyeongbuk with 63 farms and Chungnam with 62 farms. The most popular crops in 557 education farms were fruit trees. The number of fruit tree farms was 105 , followed by 76 vegetable farms and 64 flower farms (Fig. 9).

\section{Conclusion}

The analysis results of the overview of the consumer horticultural education programs in operation for the urban residents by each municipal and county Agricultural Technology Center are as follows:

There was the biggest change in the programs in 2016 compared to 2014 as 33 cities and counties started new projects. The education targets were diversified with the programs for developing the personality of elementary and middle school students in 2015 and 2016 from the lifelong education programs for adults in 2014, mostly in metropolitan cities.

In terms of the educational facilities, practical education was provided in the in-house facilities of nationwide Agricultural Technology Centers and nearby education farms. Seoul metropolitan city had the largest scale of practical 
training areas in the center sized $53.136 \mathrm{~m}^{2}$ in total and Gangwon Province had the highest number of education farms of 70. The crops with the highest educational availability were fruit trees.

The agricultural extension services, which was started in 1962 to provide lifelong education for farmers, was fast expanding into the consumer horticultural education programs in each regional Agricultural Technology Centers under the specialized programs by region as the society entered the local government system in the 1990s. Agricultural Technology Centers had lands and facilities for exiting agricultural education and the environment to use nearby farms as education farms by establishing a network. Based on the environment, they can be the hub of setting up the culture to connect farmers and urban residents through work-oriented education that not only provides agricultural knowledge to consumers but also develop their personality and sociality. It is considered that various specialized educational programs by region will be developed and used as key resources to improve the quality of education.

\section{References}

Baik, H.J. and J.B. Eom. 2015. A study on expected effect by design and effects of the horticultural therapy program on intellectual disabilities. J. Korean Soc. Flor. Art. Des. 33(0):87-116.

Jang, M. 2013. A Study on the School Farm Management in the Metropolitan Area and Connection with the Elementary Agricultural Education. MS thesis. Seoul. National univ of Education., Seoul, Korea.

Jeong, Y.M., J.H. Lee, and Y.O. Jeong. 2014. Effects of elementary school students' interest in horticultural activity on their emotional intelligence and sociability. J. Korean Pract. Art Educ. 27(3):39-54.

Kang, D.G. and H.S. Kim. 2017. College students' acceptance of therapeutic agricultural activities and occupational intention about therapeutic agricultural professional. J. Rural. Soc. 27(1):125-173.

Kweon, S.G. and O.K. Kwon. 2014. A study on forest healing facility preferred by visitors of forest healing. J. Agric. Life Sci. 48(6):97-108.

Oh, J.S. and S.Y. Kim. 2014. Study on the introduction and planning of urban agriculture within multiple housing complex - focused on the drawing planning index and ways to its application. J. Urban Des. Inst. Korea. 15(5):47-66.

Park, J.S. 2002. Study on the effective learning to labor in elementary schools of city. MS thesis, Seoul National univ of Education., Seoul, Korea.

Park, Y.J. 2008. Concept of horticultral therapy. J. Wonkwang Somat. Sci. 9(1):8-27. 